\title{
Decolorization of Orange II by Mixed Culture of Enterococcus faecalis ID6017 and Chryseobacterium indologenes ID6016
}

\author{
VINCENTIA IRENE MEITINIARTI ${ }^{1}$, KRIS HERAWAN TIMOTIUS ${ }^{2}$, ENDANG $^{2}$ \\ SUTARININGSIH SOETARTO ${ }^{3}$, AND EKO SUGIHARTO ${ }^{4}$
}

\begin{abstract}
${ }^{1}$ Faculty of Biology, Satya Wacana Christian University, Jalan Diponegoro 52-60, Salatiga 50712, Indonesia;
${ }^{2}$ Krida Wacana Christian University, Jalan Arjuna Utara 6, Jakarta 11510, Indonesia;

${ }^{3}$ Faculty of Biology, Universitas Gadjah Mada, Jalan Teknika Selatan, Yogyakarta 55281, Indonesia;

${ }^{4}$ Department of Chemistry, Universitas Gadjah Mada, Sekip Utara, Yogyakarta 55281, Indonesia
\end{abstract}

Previous work showed that Enterococcus faecalis ID6017 and Chryseobacterium indologenes ID6016 were able to decolorize the orange II qualitatively. In that experiment, E. faecalis could decolorize orange II more rapidly than $C$. indologenes. The objective of this study was to examine the decolorization of orange II by mixed culture and the growth of both bacterial species on orange II containing medium. The experiment was done in $500 \mathrm{~mL}$ sterilized Erlenmeyer flasks containing $285 \mathrm{~mL}$ growth media with $80 \mathrm{mg} \mathrm{L}^{-1}$ orange II. Five different treatments were performed in this project, i.e. medium was inoculated with (i) $15 \mathrm{~mL}$ of sterile aquadest, (ii) $15 \mathrm{~mL}$ of $C$. indologenes, (iii) $15 \mathrm{~mL}$ of E. faecalis, (iv) $7.5 \mathrm{~mL}$ of $C$. indologenes and $7.5 \mathrm{~mL}$ of E. faecalis, and (v) $7.5 \mathrm{~mL}$ of E. faecalis until decolorization occured, followed by inoculation with $7.5 \mathrm{~mL}$ of C. indologenes. Bacterial growth (total cells number), orange II, glucose, and suphanilic acid, as intermediate product of orange II decolorization, concentrations were measured every $2 \mathrm{~h}$. The maximum decolorization of orange II was observed in the medium inoculated with a mixed culture of E. faecalis and C. indologenes. Decolorization of orange II occurred of growth and gave final concentration of sulphanilic acid of $7.06 \mathrm{mg} \mathrm{L}^{-1}$. During culture both species grow in equilibrium in terms of population.

Key words: Chryseobacterium indologenes, decolorization, Enterococcus faecalis, growth, mixed culture, orange II

Penelitian sebelumnya menunjukkan bahwa Enterococcus faecalis ID6017 dan Chryseobacterium indologenes ID6016 dapat mendekolorisasi orange II secara kualitatif. Pada penelitian tersebut, E. faecalis dapat mendekolorisasi orange II lebih cepat daripada $C$. indologenes. Tujuan penelitian ini adalah menentukan dekolorisasi orange II oleh kultur campur dan pertumbuhan kedua spesies bakteri pada medium yang mengandung orange II. Penelitian dilakukan dalam botol Erlenmeyer $500 \mathrm{~mL}$ yang berisi $285 \mathrm{~mL}$ media dengan orange II $80 \mathrm{mg} \mathrm{L}^{-1}$. Penelitian dilakukan dengan 5 perlakuan, yaitu medium diinokulasi dengan (i) $15 \mathrm{~mL}$ air suling, (ii) $15 \mathrm{~mL}$ kultur C. indologenes, (iii) $15 \mathrm{ml}$ kultur E. faecalis, (iv) 7,5 mL kultur C. indologenes dan $7.5 \mathrm{~mL}$ kultur E. faecalis, dan (v) $7.5 \mathrm{~mL}$ kultur E. faecalis hingga terjadi dekolorisasi, diikuti inokulasi dengan $7.5 \mathrm{~mL}$ kultur $C$. indologenes. Pertumbuhan bakteri (jumlah sel total), konsentrasi orange II, glukose, dan asam sufanilat sebagai produk antara dekolorisasi diukur setiap 2 jam. Dekolorisasi maksimum orange II teramati pada medium yang diinokulasi dengan kultur campur E. faecalis dan C. indologenes. Dekolorisasi orange II terjadi pada 6 jam pertama kultur dan memberi konsentrasi akhir asam sulfanilat sebesar $7.06 \mathrm{mg} \mathrm{L}^{-1}$. Pertumbuhan kedua spesies bakteri berada dalam keseimbangan selama pertumbuhan ko-kultur.

Kata kunci: Chryseobacterium indologenes, dekolorisasi, Enterococcus faecalis, kultur campur, orange II, pertumbuhan

Orange II is one of synthetic azo dyes which have been widely used for textile, food, and cosmetics. Like other xenobiotic compounds, azo dyes are relatively resistant to microbial degradation under conditions normally found in wastewater treatment plants. It was reported that several microorganisms were able to transform azodyes to non-colored products or even to mineralized products (Stolz 2001).

Bacterial azodyes degradation was usually

*Corresponding author; Phone: +62-298-321212, Fax: +62298-321433,E-mail:irene_meiti@yahoo.com initiated by cleavage of azo bond carried out by azoreductase of the intestinal microflora, resulting in colorless amines (Chen et al. 2004; Ramalho et al. 2004; Kodam et al. 2005). This process is called decolorization (Tan 2001; van der Zee 2002). Anaerobic condition is more favorable for decolorization rather than aerobic condition. It is probably related to the electron with drawing nature of azo bond and the resistance of azo dyes to oxygenases attack, or because oxygen is a more effective electron acceptor than the dyes (Dos Santos 2004).

Many researchers have reported that degradation 
of azo dyes is often carried out by mixed cultures. In the mixed cultures, a higher degree of biodegradation and mineralization can be expected when co-metabolic activities within a microbial community complement each other (Pearce et al. 2003). In the anaerobic condition, orange II can be degraded by single culture of Enterococcus faecalis into sulfanilic acid as an intermediate product (Meitiniarti et al. 2007). Meitiniarti et al. (2005) also reported that Chryseobacterium indologenes could grow in the medium containing sulfanilic acid. Probably, both bacteria have synergistic relationship in orange II degradation. For this reason, our group examined the decolorization of orange II by mixed culture and the growth of both bacterial species on orange II containing medium. The aim of this study was also to determine the best mixing method of both bacterial cultures on orange II decolorization.

\section{MATERIAL AND METHODS}

Microorganism and Culture Condition. $C$. indologenes ID6016 and E. faecalis ID 6017 were obtained from Laboratory of Microbiology, Faculty of Biology, Satya Wacana Christian University, Salatiga, Indonesia. C. indologenes ID6016 and E. faecalis ID 6017 were maintained and cultivated on slant media of Nutrient Agar (NA) and Trypticase Soy Agar (TSA), respectively. Both cultures were incubated at room temperature and sub-cultured every two weeks.

Growth Medium. The composition of growth medium ( $\mathrm{pH}$ 6.8-7.2) for this study was $\left(\mathrm{g} \mathrm{L}^{-1}\right)$ : glucose, $0.90 ; \mathrm{MgSO}_{4} .7 \mathrm{H}_{2} \mathrm{O}, 0.25 ; \mathrm{KH}_{2} \mathrm{PO}_{4}, 2.13 ; \mathrm{K}_{2} \mathrm{HPO}_{4}, 5.55$; $\left(\mathrm{NH}_{4}\right)_{2} \mathrm{SO}_{4}, 1.98$; yeast extract, 0.25 ; orange II or acid orange 7, 0.08. Orange II was obtained from Merck and was used for this study without any purification.

Pre-Culture Preparation. Two inoculation needles of $C$. indologenes and $E$. faecalis from $24 \mathrm{~h}$ slant culture were inoculated aseptically into $200 \mathrm{~mL}$ growth medium without orange II. Pre-culture was incubated for 24-48 h in a shaker incubator with $150 \mathrm{rpm}$ agitation or until optical density $(\lambda 550 \mathrm{~nm}$ ) of culture was 0.4 (cell density of $C$. indologenes and $E$. faecalis were $26 \times 10^{7}$ $\mathrm{CFU} \mathrm{mL}{ }^{-1}$ and $23 \times 10^{7} \mathrm{CFU} \mathrm{mL}^{-1}$,respectively). These cultures were then used as inocula.

Culture Condition. To determine the decolorization of orange II by both bacterial cultures, the experiment was performed with 5 different treatments in $500 \mathrm{~mL}$ Erlenmeyer flasks containing $285 \mathrm{~mL}$ growth media with $80 \mathrm{mg} \mathrm{L}^{-1}$ orange II . These treatments are: (i) Medium was inoculated with $15 \mathrm{~mL}$ of sterile aquadest, (ii) Medium was inoculated with $15 \mathrm{~mL}$ of $C$. indologenes, (iii) Medium was inoculated with $15 \mathrm{~mL}$ of E. faecalis, (iv) Medium was inoculated with $7.5 \mathrm{~mL}$ of C. indologenes and $7.5 \mathrm{~mL}$ of E. faecalis, and (v) Medium was inoculated with $7.5 \mathrm{~mL}$ of E. faecalis until decolorization occured, followed by inoculating with 7.5 $\mathrm{mL}$ of $C$. indologenes. The final cell number each treatment at $0 \mathrm{~h}$ was $1.2-1.3 \times 10^{7} \mathrm{CFU} \mathrm{mL}^{-1}$.

All cultures were incubated at room temperature, under static condition until decolorization occured, followed by $150 \mathrm{rpm}$ agitation until $120 \mathrm{~h}$. Bacterial growth (total cells number), orange II and glucose concentrations, and suphanilic acid concentration as an intermediate product of orange II decolorization were observed every $2 \mathrm{~h}$.

Samples were harvested and centrifugeded at 3326 $\mathrm{g}$ for $30 \mathrm{~min}$ to separate supernatant and cell mass (biomass). The supernatant was used to determine the orange II and glucose concentrations. The ability of both bacterial strains to decolorize orange II was determined by subtracting the initial orange II concentration with the lowest concentration from samplings. The total cells number was determined by making a serial dilution of cell culture with sterile aquadest and poured $0.1 \mathrm{~mL}$ of $10^{5}-10^{7}$ cell suspension into TSA plate media.

Analytical Methods. Samples were centrifuged at $3326 \mathrm{~g}$ for $30 \mathrm{~min}$ to separate supernatant and cell mass. The supernatant was used for determining the orange II, glucose, and sulfanilic acid concentrations. Orange II concentration was determined at $\lambda 482 \mathrm{~nm}$ (Pourreza and Zareian 2009). Glucose concentration was determined using DNS method at $\lambda 540 \mathrm{~nm}$ (James 1995). The cell growth was determined using total plate count in TSA plate. In TSA plate medium, the color of $C$. indologenes colony was yellowish while $E$. faecalis was white. All absorbances were measured using Shimadzu UV-Vis 1201 Spectrophotometer. The concentration of sulfanilic acid was determined by HPLC (Coughlin et al. 1999; Chang et al. 2001; Supaka et al. 2004).

\section{RESULTS}

The growth of $C$. indologenes as a single culture was better than its growth in the mixed culture with $E$. faecalis (Fig 1A). On the contrary, the growth of $E$. faecalis together with $C$. indologenes inoculated as a mixed culture in the early experiment was faster than the growth of $E$. faecalis inoculated as a single culture (Fig 1B). Although, total numbers of E. faecalis cells in 
the mixed culture was half of its single culture, in the end of culture its total number of $E$. faecalis cells was found to be the same (Fig 1B).

The decolorization of orange II occurred when $E$. faecalis was present in the culture. The rate of orange II decolorization by mixed culture occurred faster than by single culture (Fig 2 and Table 1). When inoculation of mixed culture was done early during the experiment), the rate of orange II decolorization was found to be the fastest $\left(10.98 \mathrm{mg} \mathrm{h}^{-1}\right)$ (Table 1).

During cells growth and orange II decolorization, glucose and sulphanilic acid concentrations significantly changed (Fig 3 and 4), except when the medium was inoculated with sterile water (control) and with $C$. indologenes as single culture. However, sulphanilic acid was only detected in the first eight hours of culture, thereafter sulphanilic acid concentration decreased (Fig 4). In the growth of $C$. indologenes as a single culture, aliquot of sulphanilic acid was detected until $56 \mathrm{~h}$ incubation.

\section{DISCUSSION}

The growth of E. faecalis when co-cultured with $C$. indologenes was faster than its growth as a single culture (Fig 1B). The faster growth of E. faecalis cells caused by the presence of $C$. indologenes cells was which could consume sulphanilic acid and could decrease toxic effect of sulphanilic acid in this medium. Meitiniarti et al. (2011) reported that $C$. indologenes

A

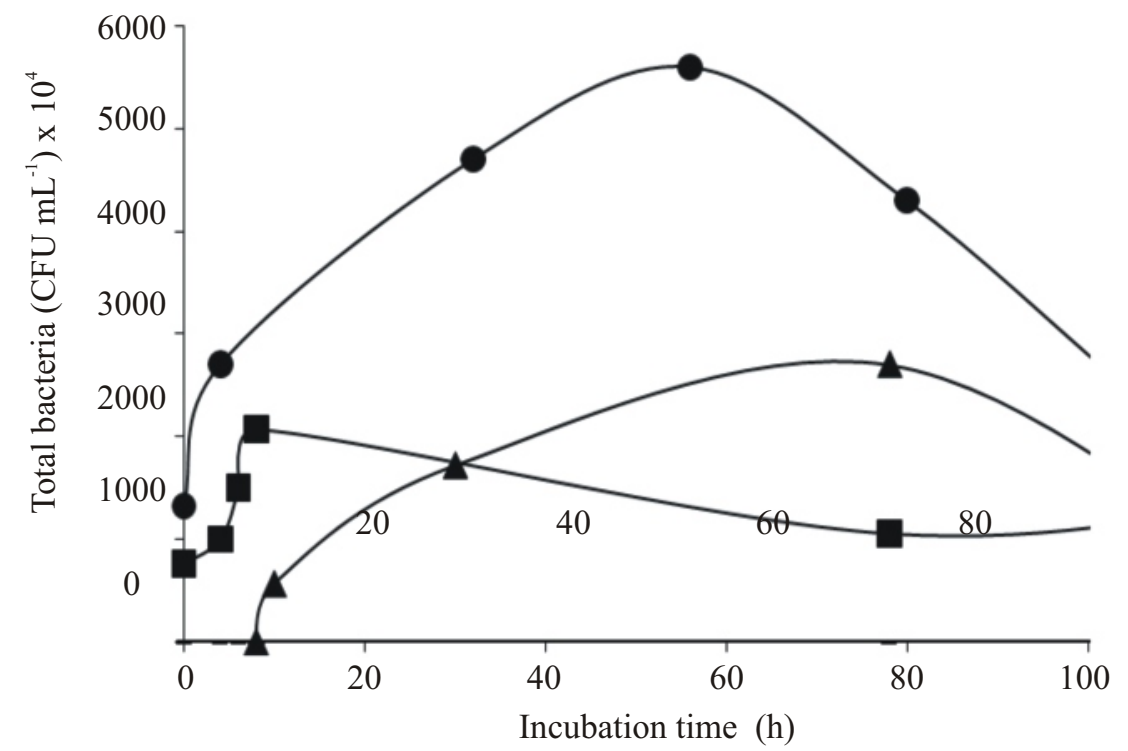

B

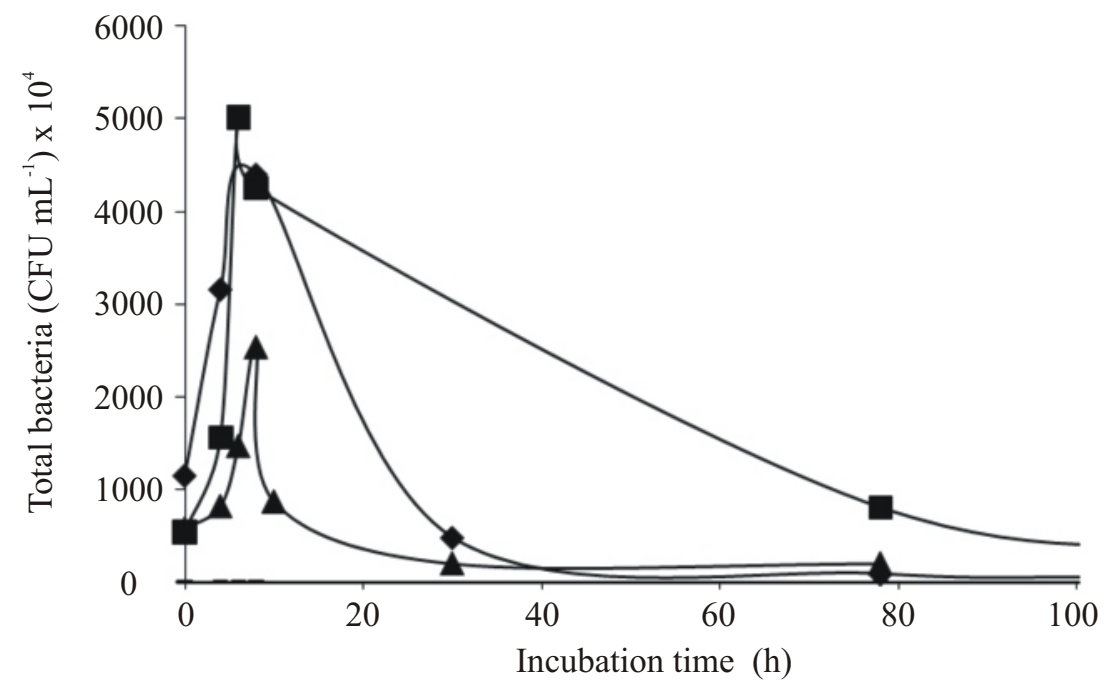

Fig 1 Total cells of Chryseobacterium indologenes (A) and Enterococcus faecalis (B) in single and mixed culture in the orange II containing medium. - : Medium was inoculated with $15 \mathrm{~mL}$ of sterile aquadest; $\bullet$ : Medium was inoculated with $15 \mathrm{~mL}$ of $C$. indologenes; :Medium was inoculated with $15 \mathrm{~mL}$ of E. faecalis; $\mathbf{\square}$ : Medium was inoculated with $7.5 \mathrm{~mL}$ of $C$. indologenes and $7.5 \mathrm{~mL}$ of $E$. faecalis ; $\mathbf{\Delta}$ : Medium was inoculated with $7.5 \mathrm{ml}$ of E. faecalis until decolorization occured, followed by inoculating with $7.5 \mathrm{~mL}$ of $C$. indologenes. 
Tab 1 Values of growth and orange II decolorization parameter by single culture of $E$. faecalis and on mixed culture with $C$. indologenes after $120 \mathrm{~h}$ incubation

\begin{tabular}{|c|c|c|c|c|c|}
\hline \multirow{2}{*}{ Parameter } & \multicolumn{5}{|c|}{ Treatments } \\
\hline & $\mathrm{i}$ & ii & iii & iv & $\mathrm{V}$ \\
\hline $\begin{array}{r}\text { Orange II reduction }(\mathrm{mg}) \\
(\%)\end{array}$ & n.dt & n.dt & $\begin{array}{l}65 \cdot 2 \pm 0 \cdot 2 \\
\quad 90 \pm 2\end{array}$ & $\begin{array}{l}65.9 \pm 0.2 \\
89 \pm 3\end{array}$ & $\begin{array}{l}69.5 \pm 0.3 \\
91 \pm 4\end{array}$ \\
\hline Time of decolorization (h) & n.dt & n.dt & 8 & 6 & 10 \\
\hline Decolorization rate $\left(\mathrm{mg} \mathrm{h}^{-1}\right)$ & n.d & n.dt & $8.15 \pm 0.02$ & $10.98 \pm 0,02$ & $6.95 \pm 0,03$ \\
\hline $\begin{array}{l}\text { Glucose consumption during } \\
\text { decolorization (mg) }\end{array}$ & n.d & n.dt & $340 \pm 7$ & $216 \pm 3$ & $393 \pm 5$ \\
\hline $\begin{array}{l}\text { Glucose consumption during } 102 \\
\mathrm{~h}(\mathrm{mg})\end{array}$ & n.d & n.dt & $710+10$ & $673+6$ & $693+4$ \\
\hline $\begin{array}{l}\text { Sulfanilic acid concentration at } \\
\text { decolorization }\left(\mathrm{mg} \mathrm{L}^{-1}\right)\end{array}$ & n.d & n.dt & $24.4+0.13$ & $23.2+1.2$ & $21.2+1.2$ \\
\hline $\begin{array}{l}\text { Sulfanilic acid concentration at } \\
128 \mathrm{~h}\left(\mathrm{mg} \mathrm{L}^{-1}\right)\end{array}$ & n.d & 1.12 & $18.5+0 \cdot 5$ & $7.06+0 \cdot 3$ & $10 \cdot 3+0 \cdot 7$ \\
\hline
\end{tabular}

n.d $=$ not detected $\quad$ n.dt $=$ not determined

$\mathrm{I}=$ first control

ii = early inoculation by Chryseobacterium indologenes (second control)

iii = early inoculation by Enterococcus faecalis (third control)

iv = early inoculation by both of $E$. faecalis and $C$. indologenes

$\mathrm{v}=$ early inoculation by $E$. faecalis, and inoculated by $C$. indologenes after decolorization

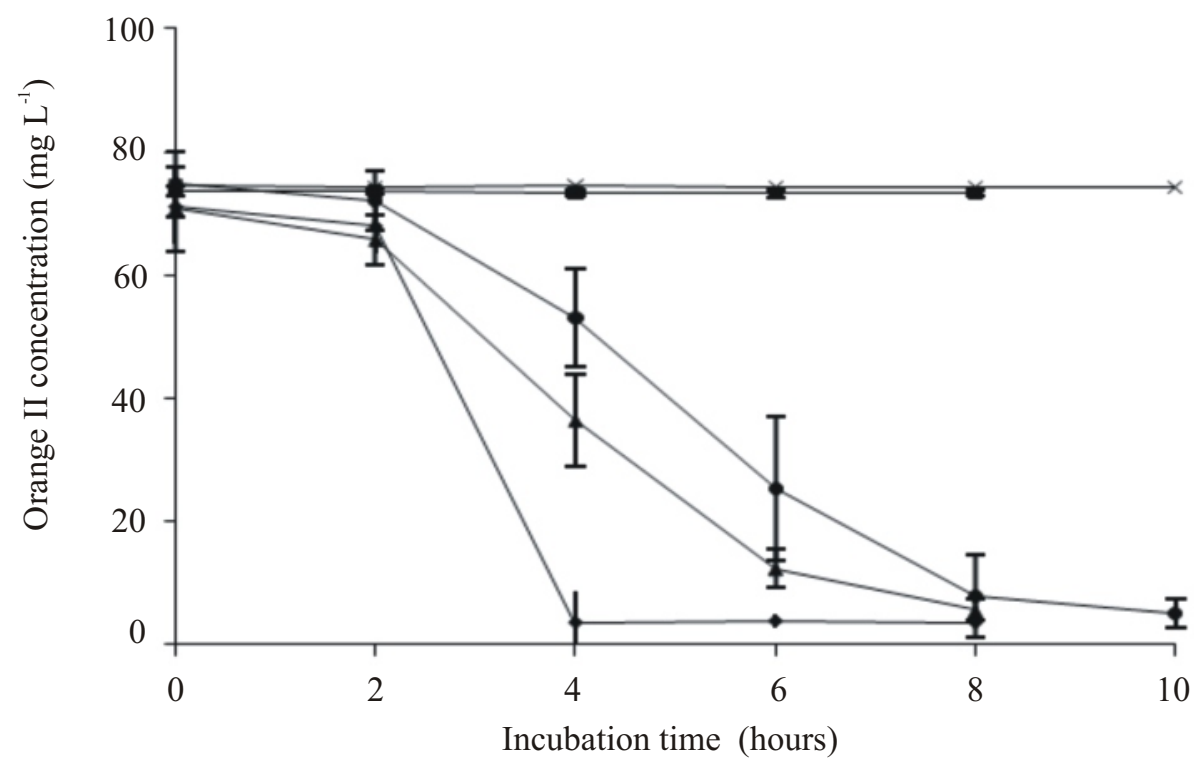

Fig 2 Decrease of orange II concentration in experiment with single culture of Enterococcus faecalis (control) and with mixed culture (together with Chryseobacterium indologenes). x: Medium was inoculated with $15 \mathrm{~mL}$ of sterile aquadest; -:Medium was inoculated with $15 \mathrm{~mL}$ of $C$. Indologenes; $\mathbf{\Delta}$ :Medium was inoculated with $15 \mathrm{~mL}$ of E. faecalis; $\checkmark$ :Medium was inoculated with $7.5 \mathrm{~mL}$ of $C$. indologenes and $7.5 \mathrm{~mL}$ of E. faecalis; $\bullet$ :Medium was inoculated with 7.5 $\mathrm{mL}$ of E. faecalis until decolorization occured, followed by inoculating with $7.5 \mathrm{~mL}$ of C. indologenes. Bars represent erros bars from three replicates.

could grow on filtrate's culture of $E$. faecalis which contained sulphanilic acid as intermediate product of orange II decolorization.

In the fifth treatment, where $C$. indologenes was inoculated after orange II decolorized, E. faecalis grew very slowly due to the low cells density of the inoculum (5\%). In low density culture, usually bacteria were less successful to colonize a natural habitat. Another factor 


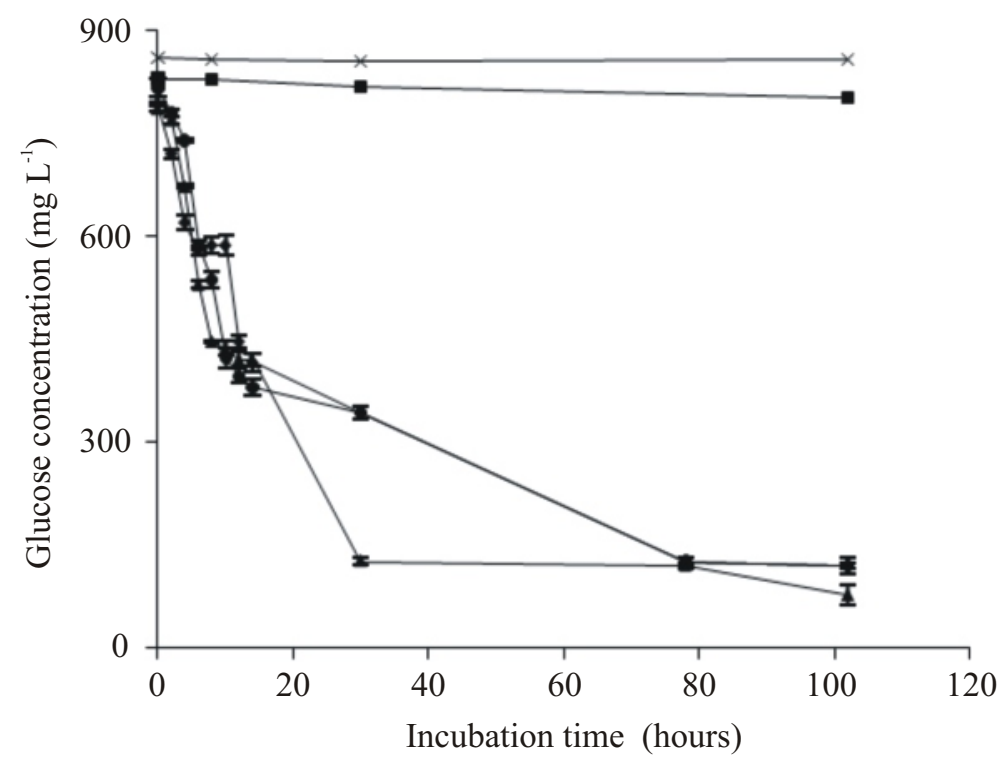

Fig 3 Change of glucose concentration in experiment with single culture of Enterococcus faecalis (control) and with mixed culture (together with Chryseobacterium indologenes). x: Medium was inoculated with $15 \mathrm{~mL}$ of sterile aquadest; $\mathbf{\square}$ : Medium was inoculated with $15 \mathrm{~mL}$ of $C$. Indologenes; $\boldsymbol{\Delta}$ :Medium was inoculated with $15 \mathrm{~mL}$ of E. faecalis; : Medium was inoculated with $7.5 \mathrm{~mL}$ of $C$. indologenes and $7.5 \mathrm{ml}$ of E. faecalis; $\bullet$ : Medium was inoculated with $7.5 \mathrm{~mL}$ of E. faecalis until decolorization occured, followed by inoculating with $7.5 \mathrm{~mL}$ of $C$. indologenes. Bars represent erros bars from three replicates.

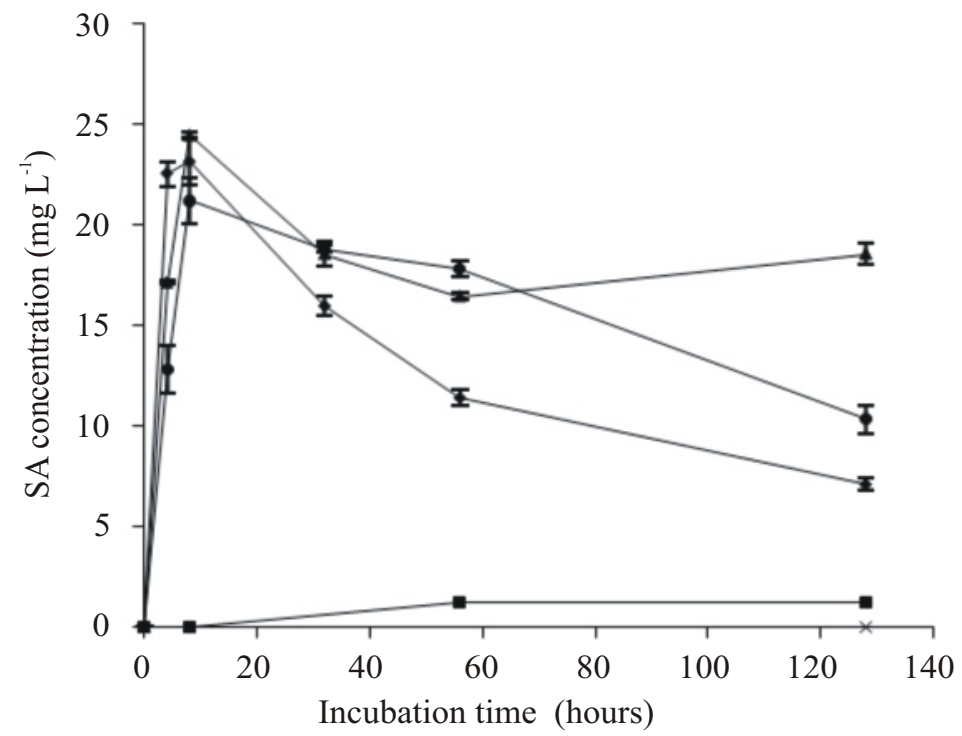

Fig 4 Change of sulphanilic acid concentration in experiment with single culture of Enterococcus faecalis (control) and mixed culture with Chryseobacterium indologenes. $\mathrm{x}$ : Medium was inoculated with $15 \mathrm{~mL}$ of sterile aquadest; $\mathbf{\square}$ :Medium was inoculated with $15 \mathrm{~mL}$ of $C$. Indologenes; $\boldsymbol{\Delta}$ :Medium was inoculated with $15 \mathrm{~mL}$ of $E$. faecalis; $\$$ :Medium was inoculated with $7.5 \mathrm{~mL}$ of $C$. indologenes and $7.5 \mathrm{~mL}$ of $E$. faecalis; $\bullet$ :Medium was inoculated with $7.5 \mathrm{~mL}$ of E. faecalis until decolorization occured, followed by inoculating with $7.5 \mathrm{~mL}$ of $C$. indologenes. Bars represent erros bars from

that might affect the culture's growth could be the existence of intermediate product of orange II decolorization that inhibits $E$. faecalis growth. This $E$. faecalis's low growth rate results in low decolorization rate.

The decreased of E. faecalis growth could be due to $E$. faecalis sensitivity to sulphanilic acid. Topaç et al. (2009) reported that the existence of sulfanilic acid $>8$ $\mathrm{mg} \mathrm{kg}^{-1}$ dry soil could decrease the number of several bacteria. On the other hand, $C$. indologenes were more resistant to sulphanilic acid and may be able use this compound as $\mathrm{C}, \mathrm{N}$, and energy sources. This ability could increase the cells number. Athough there was sulphanilic acid in the medium (fourth and fifth treatment, Table 1), the concentrations were not sufficient for $C$. indologenes growth.

If we compare the time needed for orange II decolorization and the rate of orange II decolorization 
between single culture of $E$. faecalis and mixed culture of E. faecalis and C.indologenes, it seems that orange II decolorization performed by mixed culture was better than single culture of E. faecalis (Fig 2 and Table 1). Inoculation of $E$. faecalis and $C$. indologenes as a mixed culture at the early experiment resulted higher decolorization rate than inoculation of both bacteria in a successive way. In fourth treatment, time needed for orange II decolorization was the shortest and the rate of decolorization was the fastest $\left(10.98 \mathrm{mg} \mathrm{h}^{-1}\right)$ (Table 1). This could be the result of a synergistic interaction between these two bacterial species. In this condition, decolorization product of orange II will be consumed by $C$. indologenes, so orange II decolorization activity by $E$. faecalis will occur fast and more effective. The capability of C.indologenes to consume sulphanilic acid was demonstrated by culturing of $C$. indologenes ID6016 using medium containing sulfanilic acid as C sole source also using (Meitiniarti et al. 2005) and the fitrate's culture of E. faecalis which growing on orange II containing medium (Meitiniarti et al. 2011).

The pattern of glucose consumption was similar with cell growth of E. faecalis in third and fifth treatment. Although the cell number of E. faecalis inoculated in the fifth treatment was half of that shown by the third treatment, in the end the cell numbers were similar. These conditions indicated that glucose was needed by $E$. faecalis for growth and orange II decolorization. Mendez-Paz et al. (2005) reported that the removal rate of acid orange 7 is highly favorable when glucose is added as co-substrate. Bras et al. (2001) also showed that the addition of glucose or acetate ions as electron donors, apparently stimulates the reduction cleavage of azo bonds caused the oxidation of organic electron donors and/or hydrogen is coupled to the colour removal process.

In the mixed culture, in addition to the presence of C. indologenes which could decrease toxic affect of sulphanilic acid for E. faecalis, probably $C$. indologenes could also produce intermediate products that were used as redox mediators for azoreductase produced by $E$. faecalis. In the degradation of 2naphthalene sulphonate (2NS), there are several mediator redoxs produced by Sphingomonas sp. BN6 which could transfer equivalent redoxs to azodye (Keck et al. 1997). Keck et al. (2002) proposed that these redox mediators shuttle electrons from the cells to the azo dyes, which results in purely chemical, extremely nonspecific, extracellular reductive cleavage of the azo bond. Chang et al. (2004) also reported that extracellular metabolite of Escherichia coli strain $\mathrm{NO}_{3}$ could stimulate decolorization of azodye by bacteria.

To conclude, inoculation of mixed culture of $C$. indologenes ID6016 and E. faecalis ID6017 together early during culture in orange II containing medium gave the best orange II decolorization. The rate of orange II decolorization was $10.98 \mathrm{mg} \mathrm{h}^{-1}$. Using this treatment, the best sulphanilic acid consumption (7.06 $\mathrm{mg} \mathrm{L}^{-1}$ ) and equilibrium growths of both species were achieved.

\section{REFERENCES}

Bras R, Ferra IA, Pinheiro HM, Goncalves IC. 2001. Batch tests for assessing decolourisation of azo dyes by methanogenic and mixed cultures. J Biotech. 89(23):155-62. doi: 10.1016/S0168-1656(01)00312-1.

Chang JS, Chien C, Lin YC, Lin PJ, Ho JY. 2001. Kinetic characteristics of bacterial azo dye decolorization by Pseudomonas luteola. Water Res. 35(12): 2841-2850. doi: 10.1016/S0043-1354(00)00581-9.

Chang JS, Chen BY, Lin YS. 2004. Stimulation of bacterial decolorization of an azodyes by extracellular metabolites from $E$. coli strain $\mathrm{NO}_{3}$. Bioresour Technol. 91(3): 243-248. doi: 10.1016/S0960-8524(03)00196-2.

Chen H, Wang RF, Cerniglia CE. 2004. Molecular cloning, overexpression, purification, and characterization of an aerobic FMN-dependent azoreductase from Enterococcus faecalis. Protein Expr Purif. 34(2): 302310. doi: 10.1016/j.pep.2003.12.016.

Coughlin MF, Kinkle BK, Bishop PL. 1999. Degradation of azo dyes containing aminonaphthol by Sphingomonas sp. strain 1CX. J Ind Microbiol Biotech. 23(4-5): 341346.

Dos Santos AB. 2004. Reductive decolourisation of dyes by thermophilic anaerobic granular sludge [disertation]. Wageningen [NL]: Wageningen University.

James CS. 1995. Analytical chemistry of foods. First ed. London: Blackie Academic \& Professional.

Keck A, Klein J, Kudlich M, Stolz A, Knackmuss HJ, Mattes R. 1997. Reduction of azo dyes by redox mediators originating in the naphthalenesulfonic acid degradation pathway of Sphingomonas sp. strain BN6. Appl Environ Microbiol. 63(9): 3684-3690. doi: 10.1128/AEM.68.9.4341-4349.2002.

Keck A, Rau J, Reemtsma T, Mattes R, Stolz A, Klein J. 2002. Identification of quinoide redox mediators that are formed during the degradation of naphthalene-2-sulfonate by $S$. xenophaga BN6. Appl Environ Microbiol. 68(9): 43414349. doi: 10.1128/AEM.68.9.4341-4349.2002.

Kodam KM, Soojhawon I, Lokhande PD, Gawai KR. 2005. Microbial decolorization of reactive azo dyes under aerobic conditions. World J Microbiol Biotech. 21(3): 367-370. doi: 10.1007/sI1274-004-5957-z.

Meitiniarti VI, Soetarto ES, Timotius KH, Juliana C, Vifian N, Subarkah DA. 2005. Kultivasi curah C. indologenes ID6016 pada media yang mengandung asam sulfanilat dan anilin. [Bulk cultivation of C. indologens ID6016 
on media containing sulfanilic acid and aniline]. Berkala Ilmiah Biol. 4 (6): 373-384.

Meitiniarti VI, Soetarto ES, Timotius KH, Sugiharto E. 2007. Products of orange II biodegradation by $E$. faecalis ID6017 and C. indologenes ID6016. Microbiol Indones. 1(2): 51-54.

Meitiniarti VI, Timotius KH, Haryanto. 2011. The growth of $C$. indologenes on filtrate's culture of E. faecalis which continuously growing on orange II containing medium. Proceeding of International Conference on Biological Science; 2011 Sept 23-24. Yogyakarta [ID].

Mèndez-Paz D, Omil F, Lema JM. 2005. Anaerobic treatment of azo dye acid orange 7 under batch condition. Enzyme Microb Tech. 39(5):771-778. doi: 10.1016/j.watres.2004.11.022.

Pearce CI, Lloyd JR, Guthrie JT. 2003. The removal of colour from textile wastewater using whole bacterial cells: a review. Dyes and Pigments 58: 179-196. doi: 10.1016/S0143-7208(03)00064-0.

Pourreza N, Zareian M. 2009. Determination of Orange II in food samples after cloud point extraction using mixed micelles. J Hazard Mater. 165(1-3):1124-1127. doi: 10.1016/j.jhazmat.2008.10.132.
Ramalho PA, Cardoso MH, Cavaco-Paulo A, Ramalho MT. 2004. Characterization of azo reduction activity in a novel Ascomycete yeast strain. Appl Environ Microbiol. 70(4): 2279-2288. doi:10.1128/AEM.70.4.22792288.2004.

Stolz A. 2001. Basic and applied aspects in the microbial degradation of azo dyes. Appl Microbiol Biotech. 56(12): 69-80. doi: 10.1007/s002530100686.

Supaka N, Juntongjin K, Damronglerd S, Delia ML, Strehaiano P. 2004. Microbial decolorization of reactive azo dyes in a sequential anaerobic-aerobic system. Chem Eng J. 99(2): 169-176. doi: 10.1016/j.cej.2003.09.010.

Tan NCG. 2001. Integrated and sequential anaerobic/aerobic biodegradation of azo dyes [disertation]. Wageningen [NL]: Wageningen University.

Topaç FO, Dindar E, Uçaroğlu S, Başkaya HS. 2009. Effect of a sulfonated azo dye and sulfanilic acid on nitrogen transformation processes in soil. J Hazard Mater. 170 (23):1006-1013. doi: 10.1016/j.jhazmat.2009.05.080.

Van der Zee FP. 2002. Anaerobic azo dye reduction [disertation]. Wageningen [NL]: Wageningen University. 